\title{
Production of Salt Tolerant Thevetia peruviana Schum. Plants by Tissue Culture
}

\author{
Hoda I. M. El-Gedawey
}

\begin{abstract}
Salt stress is a serious problem plant production and one of the main causes of damage on growth crops in the world. The plants are different in their ability to grow under salt stress. There are many studies to determine the plants salt tolerantce. This study was carried out in the tissue culture laboratory, Faculty of Agric., Saba Basha, Alex. Univ. to find a reliable protocol for in vitro propagation of Thevetia peruviana Schum. during the period from 2019 to 2020 was developed. Moreover, nodal explants were used during in vitro culture study for indication of multiple shoots and were inculated on various media with different combinations of NAA and KIN to study the effect on proliferation and development of multiple shoots, and the elongation of the newly formed on medium. The best medium for multiplication was a medium supplemented with3.00 and $4.00 \mathrm{mg} / \mathrm{l}$ KIN and $0.50 \mathrm{mg} / \mathrm{l}$ NAA. Furthermore, the in vitro shoots showed healthy root development when the tested medium was supplemented with combination of 1.00 or $2.00 \mathrm{mg} / \mathrm{l}$ IBA and $0.50 \mathrm{mg} / \mathrm{l}$ NAA. The newly formed shoot plantlets are selected for resistance to salt, and laboratory in vitro techniques proved very useful for this prupose. The plants showed good tolerance under low salt concentration at 2and $4 \mathrm{gL}^{-1} \mathrm{NaCl}$ on multiplication of explants shootlets of thevetia plants with good survival. At the the salt concentration of $6 \mathrm{gL}^{-1}$, showed inhibitory effect on growth of plants with reduced the shootlets length, number of shoots, number of leaflets and number of roots/shootlets. Moreover, the proportion of carbohydrate content increased with the increasing salt concentration.
\end{abstract}

Key words: in vitro, Thevetia peruviana Schum. multiplication, $\mathrm{NaCl}$, Salt stress.

\section{INTRODUCTION}

Thevetia peruviana (pers.) Schum. (familyApocynaceae), commonly known as yellow Oleander and Luky nut, is one of the most important medicinal shrubs. It is an evergreen small ornamental tree, which grows up to a height of about 10-15 feet. Thevetia peruviana is a plant probably native to Central and South America but now frequently grown throughout the tropical and sub- tropical regions of the world, and they are conventionally propagated by seeds. This plant species produces several compounds with industrial application as pharmaceutical compounds, such as cardiac glucosides neriifolin, thevetoxin, peruvoside,

DOI: 10.21608/asejaiqjsae.2021.155566

${ }^{1}$ Agriculture research center, Horticulture Institute, Ministry of Agric., Deprt. of Ornamental \& Landscape Gardening, Antoniadis, Alex.

Received February 10, 2021, Accepted March 10, 2021 and thevetin A and B (Omino and Kokwaro, 1993). It contains a milky sap containing a compound-thevein that is used as a heart stimulant but in its natural form it is extremely poisonous, as all parts of the plants, especially the seeds. In Thevetia, the milky juice that exudes when cutting any part of the plant yields the toxic principles. Toxicity may occur from consuming teas brewed from plant parts.

Unfortunately, cuttings of this plant do not root easily or even do not root at all, however, many approaches have been adopted to overcome this obstacle. Hence, tissue culture technique represents a promising means to solve this problem (AbdulQader,1999).

Tissue culture is a propagation technique widely used in modern agriculture because it allows production of many clonal of plants from relatively little starting material. Micropropagation is a relatively new technology and innovative method that has served to overcome barriers to progress in the multiplication of elite species and further improvments are anticipated (Nasib et al.,2008; Ashish and Sharma, 2011). Few reports are available regarding the tissue culture of this medicinally plant species (Kumar,1992).

Salt stress is an important factor causing plant damage in horticulture. It has a major effect on agriculture productivity. Salinity impact almost on all aspects of plant growth and development. The responses to salinity vary not only among the different ornamental crops but also among the different organs of plant ( Kucukahmetler, 2002).

In vitro techinques can be used as a tool for including salt stress. The advantages of tissue culture include quick regeneration of plants and easiness of control of ambient conditions (Pawlowska and Bach, 2010). This study aimes to at producting the plants under effect of salinity by supplementing the medium culture with $\mathrm{NaCl}$ and determining the effect of salinity effect on growth and development of Thevetia peruviana under in vitro culture. 


\section{MATERIAL AND METHODS}

\section{Plant material and explant sterilization}

The plant material was collected from shrubs grown in Antoniadis garden of Ornamental and Landscape, Research Department, Alexandria, Egypt. Plants were sprayed with the fungicide and insecticide 2-3 weeks prior to start initiation and overhead watering was strictly avoided. Freshly grown shoot tips, with two to three nodes, were selected as explants source in August. The collected material was brought to the plant tissue culture laboratory of the Plant Production Department of the Faculty of Agriculture, Saba Basha, Alexandria Unviversity during 2019-2020 seasons and washed, thoroughly, with running tap water for 30 minutes to remove the dust or sand particles.

The shoot tips were cut to nodal segments (single node) as an explants source (Bhattatcharya et al.,1990). The excised explants were dipped in $70 \%$ ethanol for 1 min. After treatment with ethanol the explants were then rinsed with double distilled water twice, so as to lower the toxic effect of ethanol. The nodal segment's surfaces were sterilized using $30 \%$ of sodium hypochlorite $(\mathrm{NaOCl})$ solution (commercial bleach as 'clorox') for 15 minutes and $1.00 \mathrm{mg} / \mathrm{l}$ mercuric chloride $\left(\mathrm{HgCl}_{2}\right)$ for $5 \mathrm{~min}$. Few drops of Tween-20, were also, added as a surfactant to sterilized water with sterile gentle shaking under sterile conditions, the plant material was washed five times with sterilized water and became ready for culture.

\section{Micropropagation stages}

\section{Intiation stage:}

The explants were cultured on WPM medium (woody plant medium) (Lloyd and McCown,1980) supplemented by five different concentrations of kinetin (KIN) 0.0 (nil), $0.50,1.00,1.50$, and $2.00 \mathrm{mg} / 1$ in combinations with the auxin naphthalene acetic acid (NAA) at five concentrations: 0.0 (nil), $0.50,1.00,2.00$ and $3.00 \mathrm{mg} / \mathrm{l}$.

The explants were cultured in jars containing $30 \mathrm{ml}$ of medium and were placed vertically. Each treatment was replicated three times and it had five explants (i.e.15 explants/tretement). The jars were capped with aluminum foil closures and incubated in growth chamber at $25 \pm 1^{\circ} \mathrm{c}$ temperature and $80 \%$ for humidity under $16 \mathrm{hr}$ daily light and $8 \mathrm{hr}$ darkness illumination by a florescent light intensity of $2880 \mathrm{lux}\left(40 \mu \mathrm{mol} \mathrm{m}^{-2} \mathrm{~S}\right.$ $\left.{ }^{1} \mathrm{PPF}\right)$. The explants in the intiation stage were cultured for 35 days on solidified woody plant medium was adjusted to $5.7 \pm 0.1 \mathrm{pH}$ value.

\section{Multiplication stage:}

The neoformed propagules of the initiation stage were sectioned into single leaflet nodes. The excised nodal cutting explants of the different positions were cultured randomly onto the multiplication medium (WPM) supplemented with KIN at five concentrations: 0.0 (nil), $1.00,2.00,3.00$ and $4.00 \mathrm{mg} / \mathrm{l}$, in combinations with NAA at five concentrations: 0.00 (nil), $0.25,0.50$, 1.00 , and $2.00 \mathrm{mg} / \mathrm{l}$.

\section{Rooting (rhizogenesis) stage:}

Thevetia shoots of from the multiplication stages were separated and cultured on a rooting medium for rhizogensis. This medium was supplemented by two types of auxins which were used as indole butyric acid (IBA) at five concentrations: 0.0 (nil), 0.50, 1.00, 2.00 and $3.00 \mathrm{mg} / \mathrm{l}$ in combionations with NAA at five concentrations: $\quad 0.0($ nil $), 0.25,0.50,0.75$ and $1.00 \mathrm{mg} / 1$ Generally, the data were measured after 35 days from culture.

The data was recorded per propagule at initiation, multiplication and rooting stages after 35 days from culture. The tested characters were as follows:

-Average shoots length $(\mathrm{cm}) /$ prppagule.

-Average number of shoots formed/propagule.

-Average number of leaflets formed/propagule.

-Average number of roots formed/propagule.

\section{WPM- Salt exprement:}

Micro shoots (5mm, with 2-3 leaves) of newlyformed shoots from multiplaction stage of thevetia were cultured in medium supplemented with4 $\mathrm{mg} / \mathrm{l} \mathrm{KIN}$ and $0.50 \mathrm{mg} / \mathrm{l} \mathrm{NAA}$. The tested medium was suplplemented with $\mathrm{NaCl}$ at four concentrations: 0.00 , 2,4 and $6 \mathrm{~g} / \mathrm{L}^{-1}$. Three replications for each treatment with 5 explants of each jar was containing $30 \mathrm{ml}$ of medium were tested. The jar with cultures were mainted in a growth room for 6 weeks. The following data was recorded after 6 weeks: number of shoots, shoot length $(\mathrm{cm})$, number of leaflets, number of roots, fresh weight, and dry weight (after drying at $60^{\circ} \mathrm{c}$ to constant mass), survival rate of shootlets $(\%)$.

\section{Acclimatiztion stage:}

The newformed plantlets were then transferred to the greenhouse for gardening. The potting mix used in this study was comprised of sand and soil (1:3). The transferred plants were monitored weekly for at least 6 weeks. Successful adaption percentage data was transformed using angular transformation before analysis. 


\section{Statistical analysis:}

A completely randomized design was used for all the experiments (Gomez and Gomez,1984). Recorded data was analyzed statistically using analysis of variance technique (SAS), averages were compared by the least significant difference (L.S.D.) (Steel et al.,1997) and significance was determined at $\mathrm{p} \leq 0.05$.

\section{Chemical analysis:}

Chlorophyll a and b content (mg/100g fresh weight) was determined in leaves according to Moran (1982), carotenoids $(\mathrm{mg} / 100 \mathrm{~g}$ fresh weight) according to Wellburn (1994). Total carbohydrate content (\%) according to (Hedge and Hofreiter 1962). Proline content $(\mu \mathrm{g} / \mathrm{g}$ dry weight) was determined according to Bates et al. (1973). The all chemical analysis were done on the shoots produced in vitro. (Sawsan et al 2005; Abou Dahab et al.2005).

\section{RESULTS AND DISCUSSION}

The results in Table (1) indicated, generally, that appling both growth regulators, NAA and KIN levels and their interactions exerted highly significant effects on the intiation stage tarties of single node explants of Thevetia peruaiana grown in vitro for 35 days as shown in photo (1). Concerning the main effect of KIN on the studied characters, i.e. shoot length, number of shoots, leaflets, formed per propagule, there was a proportional relationship between KIN levels and the given trait. Using KIN in culture medium resulted the number of roots was in an adverse relationship where as KIN level increase the given trait decrease.

However, the highest mean values were always recorded at KIN $(2.00 \mathrm{mg} / \mathrm{l})$. Regarding the average using NAA all studied trait increased except the highest level which gave the lowest result were noticed at $3.00 \mathrm{mg} / \mathrm{l}$.

Concerning of the interaction between levels of both factors under the study, the presence of two hormones, KIN at levels of $(1.50$ or $2.00 \mathrm{mg} / \mathrm{l})$ and NAA at levels of 1.00 or $2.00 \mathrm{mg} / \mathrm{l}$, led to the highest mean values of the most studied characters particularly number of shoots and number of leaftlets. But the absence of KIN levels of $(0.00$ or $0.50 \mathrm{mg} / \mathrm{l})$ and NAA at $2.00 \mathrm{mg} / 1$, led to the highest mean values of number of roots (2.63). In general, using KIN in culture medium resulted in an adverse relationship between the number of roots and the given trait these results could be about to the mod of action of cytokinins which stimulate cell division and promotes growth of axillary shoots in palnt tissues culture. This is in concordance with the previous study of George et al. (2008). Lemos and Black (1996) who showed that the addition of NAA promoted bud elongation of Annona muricata.

Concerning the explants cultured on WPM medium, data representing of node explant in multiplication stage showed positive response with absense $\mathrm{KIN}($ nil $=0.00)$ and $2.00 \mathrm{mg} / \mathrm{l}$ NAA which gave the highest shoot length $(3.65 \mathrm{~cm})$. While mean the best number of shoots $(4.26 \& 4.16)$ and number of leaflets $(18.18 \& 18.08)$ were recorded with NAA at $0.50 \mathrm{mg} / \mathrm{l}$ and KIN3.00 or $4.00 \mathrm{mg} / \mathrm{l}$, respectively in Table (2) photo (2).

In contrast, when shoots cultured on medium they showed good signs and best roots on the multiplication stage when the medium supplemented with the highest concentration of NAA at $2.00 \mathrm{mg} / \mathrm{l}$.

In this respect, the used cytokinin (KIN) gave the highest results in the studied trait in culture media because it favours stimulation of cell division, morphogenesis (shoot intiation/bud formation) in tissue cultured, and break of apical dominance and release growth of lateral buds (Raven et al. 1992; Salispury and Ross,1992; Davies,1995) and exerted highely significant effects on the multiplication stages characters, where single nodal explants were grown in vitro for 35 days .

With regard to the number of leaflets, cytokinins together with auxin, take part in the regulation of the cell cycle in plant cells (i,e. stimulation of cell division, break apical dominance, enhancement axillary of shoot proliferation, and adventitious and inhibition root formation. Chitra and Madhusoodanan (2005) who studied the influence of auxins in direct in vitro and presented a scenario for future prospects of tissue culture.

This finding could be achieved due to the mode of action of auxin within cultured tissues which may enhance and control various distinctive processes such as cell growth and elongation (George and Sherrington, 1984 and Wilkins, 1989).

Also, an explanation for this phenomenon, it is more likely that high levels of KIN utilized in this study (3.00or $4.00 \mathrm{mg} / \mathrm{l}$ ) and elsewhere, too, may have caused the removal of apical dominance thus enhancing lateral shoot proliferation (Klimazewska,1981). Sana et al. (2012) reported that the enhanced shoots and buds proliferation formation can be achieved by using the MS medium with $2 \mathrm{mg} / \mathrm{l}$ of both KIN and BA for Codiaeum pictum or $4 \mathrm{mg} / \mathrm{l}$ of both cytokinin. 
Table 1. Effect of different levels of KIN, NAA (mg/l) and their combinations on the initiation stage of Thevetia peruviana (Pres.) Schum. nodal cuttings cultured in vitro for 35 days

\begin{tabular}{|c|c|c|c|c|c|c|c|c|c|c|}
\hline \multirow[b]{2}{*}{ Characters } & \multirow{2}{*}{$\begin{array}{l}\text { NAA } \\
\text { levels } \\
\text { (mg/l) }\end{array}$} & \multicolumn{5}{|c|}{ KIN levels (mg/l) } & \multirow{2}{*}{$\begin{array}{l}\text { Mean } \\
\text { NAA }\end{array}$} & \multicolumn{3}{|c|}{ Significance } \\
\hline & & 0.00 & 0.50 & 1.00 & 1.50 & 2.00 & & KIN & NAA & KINXNAA \\
\hline \multicolumn{11}{|c|}{ (a) Mean shoot length $(\mathrm{cm}) /$ propagule : } \\
\hline & 0.00 & 0.62 & 1.85 & 0.86 & 0.74 & 0.74 & 0.98 & $*$ & $* *$ & $* *$ \\
\hline & 0.50 & 1.20 & 1.47 & 3.00 & 3.96 & 2.26 & 2.38 & & & \\
\hline & 1.00 & 2.43 & 2.63 & 3.38 & 3.36 & 3.46 & 3.05 & & & \\
\hline & 2.00 & 2.84 & 2.75 & 2.17 & 1.99 & 1.52 & 2.32 & & & \\
\hline & 3.00 & 2.60 & 1.76 & 1.73 & 1.63 & 1.56 & 1.85 & & & \\
\hline Mean (KIN) & & 2.00 & 2.09 & 2.24 & 2.34 & 1.91 & & & & \\
\hline L.S.D.(0.05) & & & & & & & & 0.26 & 0.26 & 0.61 \\
\hline \multicolumn{11}{|c|}{ (b) Mean number of shoots formed /propagule: } \\
\hline & 0.00 & 0.00 & 0.00 & 1.33 & 1.93 & 2.00 & 1.05 & $* *$ & $* *$ & $*$ \\
\hline & 0.50 & 1.00 & 1.33 & 1.80 & 2.33 & 2.00 & 1.69 & & & \\
\hline & 1.00 & 1.66 & 2.26 & 2.67 & 2.20 & 1.86 & 2.13 & & & \\
\hline & 2.00 & 2.00 & 2.13 & 2.55 & 2.60 & 2.66 & 2.40 & & & \\
\hline & 3.00 & 1.00 & 1.66 & 1.66 & 2.00 & 2.33 & 1.66 & & & \\
\hline Mean (KIN) & & 1.13 & 1.48 & 2.0 & 2.16 & 2.17 & & & & \\
\hline L.S.D. $(0.05)$ & & & & & & & & 0.35 & 0.35 & 0.78 \\
\hline \multicolumn{11}{|c|}{ (c) Mean number of leaflets formed /prpbagule: } \\
\hline & 0.00 & 2.71 & 2.79 & 2.16 & 4.75 & 3.86 & 3.65 & $* *$ & $* *$ & $* *$ \\
\hline & 0.50 & 4.50 & 3.59 & 4.06 & 9.52 & 9.51 & 6.19 & & & \\
\hline & 1.00 & 5.75 & 7.30 & 9.60 & 9.00 & 9.00 & 8.13 & & & \\
\hline & 2.00 & 5.72 & 7.66 & 9.00 & 10.41 & 9.33 & 8.47 & & & \\
\hline & 3.00 & 3.30 & 5.03 & 5.39 & 5.73 & 5.33 & 5.02 & & & \\
\hline $\operatorname{Mean}(\mathrm{KIN})$ & & 4.39 & 5.27 & 6.56 & 7.81 & 7.40 & & & & \\
\hline L.S.D. $(0.05)$ & & & & & & & & 0.74 & 0.74 & 1.67 \\
\hline \multicolumn{11}{|c|}{ (d) mean number of roots formed /propagule: } \\
\hline & 0.00 & 0.00 & 1.23 & 1.06 & 0.00 & 0.00 & 0.46 & $* *$ & $* *$ & $* *$ \\
\hline & 0.50 & 1.53 & 1.43 & 0.70 & 0.40 & 0.43 & 0.90 & & & \\
\hline & 1.00 & 2.00 & 2.40 & 0.93 & 1.00 & 0.33 & 1.33 & & & \\
\hline & 2.00 & 2.63 & 2.00 & 1.26 & 1.33 & 0.76 & 1.60 & & & \\
\hline & 3.00 & 2.00 & 1.43 & 1.00 & 0.33 & 0.33 & 1.02 & & & \\
\hline Mean (KIN) & & 1.63 & 1.63 & 0.99 & 0.61 & 0.44 & & & & \\
\hline L.S.D.(0.05) & & & & & & & & 0.26 & 0.26 & 0.60 \\
\hline
\end{tabular}

L.S.D. (0.05) =Least significant difference test at 0.05 level of probability*, **: Significant or highly significant.

On the other hand, EL-Shamy et al. (2010) reported that the best medium for Magnolia grandiflora at the multiplication stage, was WP medium plus the growth regulators of KIN at 5.00 or $6.00 \mathrm{mg} / \mathrm{l}$ which increased plant height, number of leaves/shoot and number of shoots. Zibbu and Batra (2010) also found that in vitro leaves of Thevetia cultured on MS medium supplemented with a combination of 2,4-D $(2.5 \mathrm{mg} / \mathrm{l})$ and KIN (1or2 $\mathrm{mg} / \mathrm{l}$ ) produced stock callus after 20-28 days of inculation. Also, Priyanaka et al. (2011) reported that nodal segments of Thevetia peruviana responded with a maximum of $100 \%$ frequency of callus induction on a combination of $9.05 \mu \mathrm{M}(2 \mathrm{ppm})$ 2,4-D and $0.93 \mu \mathrm{M}(0.2 \mathrm{ppm}) \mathrm{KIN}$, followed by frequency of $88.3 \%$ on $6.97 \mu \mathrm{M}(1.5 \mathrm{ppm}) \mathrm{KIN}$, supplemented alone. Taha et al. (2011) found that Thevetia neriifolia Jussieu. and T. thevetioides Kunth. which was established on MS medium supplemented with $1 \mathrm{mg} / \mathrm{l} 2,4 \mathrm{D}+3 \mathrm{mg} / \mathrm{l} \mathrm{KIN}$ showed the best results of mass calli production. And the explants of T.neriifolia exhibited high degree of multiple shootlets proliferation on MS+ $1 \mathrm{mg} / 12,4 \mathrm{D}+3 \mathrm{mg} / \mathrm{l}$ bap from stem explants as compared with T.thevetioides. Nesy et al. (2015) recorded that the best organogenesis in grown internode explants of Thevetia neriifolia response was achieved with a combination of IBA+BA $(0.5+1.0 \mathrm{mg} / \mathrm{l})$. However, better response for maximum shoot proliferation was achieved when BA $(1.0 \mathrm{mg} / \mathrm{l})$ was supplied individually. 


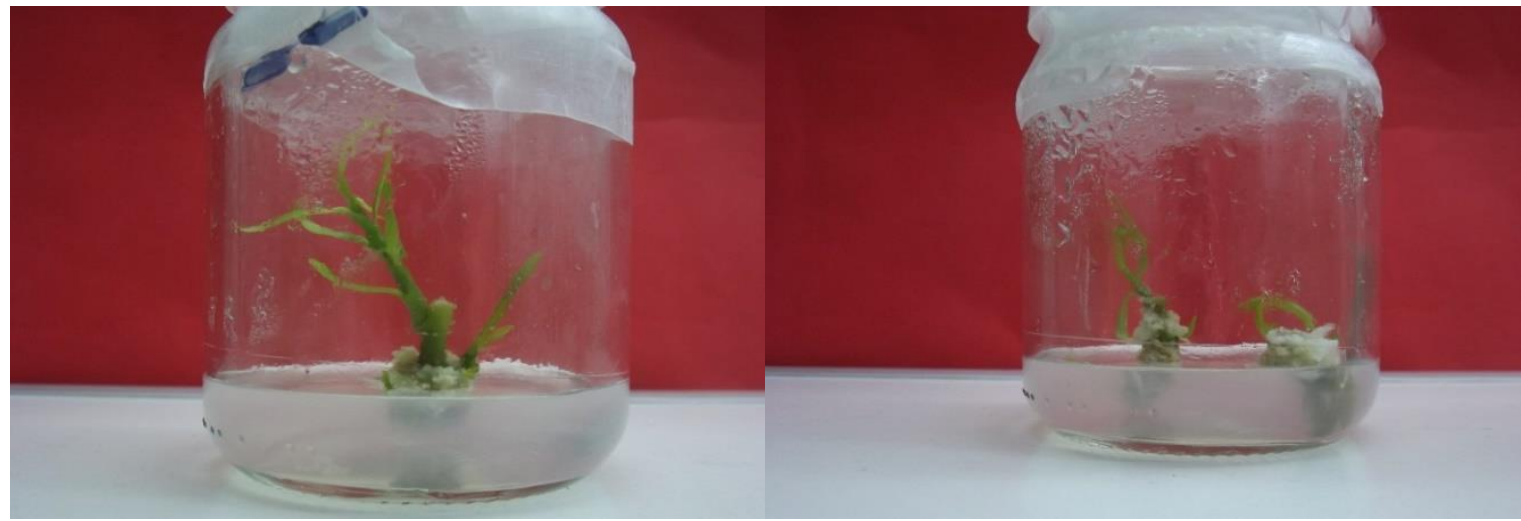

Photo 1. Initiation stage of Thevetia nodal explants cultured on WPM at 2mg / NAA only

Table 2. Effect of different levels of KIN, NAA (mg/l) and their combinations on the multiplication stage of Thevetia peruviana Schum. nodal cuttings cultured in vitro for 35 days

\begin{tabular}{|c|c|c|c|c|c|c|c|c|c|c|}
\hline \multirow[b]{2}{*}{ Characters } & \multirow{2}{*}{$\begin{array}{l}\text { NAA } \\
\text { levels } \\
\text { (mg/l) }\end{array}$} & \multicolumn{5}{|c|}{ KIN levels (mg/l) } & \multirow[b]{2}{*}{$\begin{array}{c}\text { Mean } \\
\text { NAA }\end{array}$} & \multicolumn{3}{|c|}{ Significance } \\
\hline & & 0.00 & 1.00 & 2.00 & 3.00 & 4.00 & & KIN & NAA & KIN x NAA \\
\hline \multicolumn{11}{|c|}{ (a) Mean shoot length $(\mathrm{cm}) /$ propagule : } \\
\hline & 0.00 & 1.27 & 1.71 & 1.55 & 1.27 & 1.13 & 1.38 & *** & *** & $* *$ \\
\hline & 0.25 & 2.44 & 2.71 & 2.61 & 2.72 & 2.16 & 2.39 & & & \\
\hline & 0.50 & 2.83 & 3.63 & 3.12 & 2.27 & 2.23 & 2.74 & & & \\
\hline & 1.00 & 2.47 & 3.29 & 2.91 & 2.50 & 2.06 & 2.67 & & & \\
\hline & 2.00 & 3.65 & 3.26 & 2.89 & 2.30 & 1.80 & 2.78 & & & \\
\hline Mean (KIN) & & 2.55 & 2.78 & 2.55 & 2.22 & 1.87 & & & & \\
\hline L.S.D. $(0.05)$ & & & & & & & & 0.16 & 0.16 & 0.36 \\
\hline \multicolumn{11}{|c|}{ (b) Mean number of shoots formed /propagule : } \\
\hline & 0.00 & 1.00 & 1.22 & 1.59 & 1.55 & 1.39 & 1.35 & $* *$ & *** & ** \\
\hline & 0.25 & 2.14 & 2.44 & 3.16 & 3.35 & 3.16 & 2.85 & & & \\
\hline & 0.50 & 1.92 & 2.79 & 3.80 & 4.26 & 4.16 & 3.40 & & & \\
\hline & 1.00 & 2.11 & 2.35 & 3.33 & 3.38 & 3.22 & 2.88 & & & \\
\hline & 2.00 & 2.16 & 2.25 & 3.10 & 3.10 & 3.00 & 2.73 & & & \\
\hline Mean $(\mathrm{KIN})$ & & 1.86 & 2.21 & 3.02 & 3.13 & 2.98 & & & & \\
\hline L.S.D.(0.05) & & & & & & & & 0.23 & 0.23 & 0.51 \\
\hline \multicolumn{11}{|c|}{ (c) Mean number of leaflets formed /prpbagule: } \\
\hline & 0.00 & 2.62 & 4.23 & 7.58 & 7.33 & 7.43 & 15.83 & $* *$ & $* *$ & $* *$ \\
\hline & 0.25 & 7.49 & 8.15 & 9.82 & 14.08 & 16.17 & 11.20 & & & \\
\hline & 0.50 & 8.34 & 14.31 & 17.33 & 18.18 & 18.08 & 15.31 & & & \\
\hline & 1.00 & 11.21 & 13.23 & 15.75 & 12.86 & 15.27 & 13.73 & & & \\
\hline & 2.00 & 11.85 & 12.47 & 12.14 & 12.50 & 12.48 & 12.28 & & & \\
\hline Mean(KIN) & & 8.30 & 10.47 & 12.52 & 12.99 & 14.07 & & & & \\
\hline L.S.D.(0.05) & & & & & & & & 0.82 & 0.82 & 1.84 \\
\hline \multicolumn{11}{|c|}{ (d) mean number of roots formed /propagule: } \\
\hline & 0.00 & 1.14 & 1.83 & 1.74 & 1.48 & 0.67 & 1.37 & $* *$ & *** & n.s. \\
\hline & 0.25 & 3.0 & 3.10 & 3.23 & 2.10 & 1.70 & 2.42 & & & \\
\hline & 0.50 & 3.77 & 3.97 & 3.67 & 3.10 & 2.97 & 3.49 & & & \\
\hline & 1.00 & 5.03 & 4.17 & 4.44 & 4.19 & 4.07 & 4.38 & & & \\
\hline & 2.00 & 6.14 & 4.57 & 4.70 & 4.41 & 4.38 & 4.83 & & & \\
\hline Mean (KIN) & & 3.81 & 3.52 & 3.35 & 3.05 & 2.75 & & & & \\
\hline L.S.D.(0.05) & & & & & & & & 0.42 & 0.42 & ------ \\
\hline
\end{tabular}

L.S.D. $(0.05)=$ Least significant difference test at 0.05 level of probability*, **: Significant or highly significant. 
Table 3. Effect of different levels of NAA, IBA $(\mathrm{mg} / \mathrm{l})$ and their combinations on the rooting stage of Thevetia peruviana Schum. nodal cuttings cultured in vitro for 35 days

\begin{tabular}{|c|c|c|c|c|c|c|c|c|c|c|}
\hline \multirow{2}{*}{ Characters } & \multirow{2}{*}{$\begin{array}{c}\text { IBA } \\
\text { levels } \\
(\mathrm{mg} / \mathrm{l})\end{array}$} & \multicolumn{5}{|c|}{ NAA levels (mg/l) } & \multirow{2}{*}{$\begin{array}{c}\text { Mean } \\
\text { IBA }\end{array}$} & \multicolumn{3}{|c|}{ Significance } \\
\hline & & 0.00 & 0.25 & 0.50 & 0.75 & 1.00 & & NAA & IBA & NAA $x$ IBA \\
\hline \multicolumn{11}{|c|}{ (a) Mean shoot length $(\mathrm{cm}) /$ propagule : } \\
\hline & 0.00 & 2.84 & 3.97 & 4.40 & 4.30 & 4.17 & 3.93 & ** & $* *$ & $*$ \\
\hline & 0.50 & 3.83 & 6.72 & 6.89 & 6.31 & 6.27 & 6.00 & & & \\
\hline & 1.00 & 4.45 & 7.21 & 8.22 & 7.41 & 7.02 & 6.86 & & & \\
\hline & 2.00 & 4.68 & 5.42 & 5.43 & 5.76 & 4.36 & 5.13 & & & \\
\hline & 3.00 & 4.50 & 4.70 & 4.77 & 5.13 & 3.50 & 4.52 & & & \\
\hline Mean (NAA) & & 4.02 & 5.60 & 5.94 & 5.91 & 5.06 & & & & \\
\hline L.S.D. $(0.05)$ & & & & & & & & 0.62 & 0.62 & 1.41 \\
\hline \multicolumn{11}{|c|}{ (b) Mean number of shoots formed /propagule: } \\
\hline & 0.00 & 1.10 & 2.24 & 1.66 & 1.51 & 1.52 & 1.60 & $* *$ & $* *$ & $* *$ \\
\hline & 0.50 & 1.52 & 1.42 & 1.65 & 1.22 & 1.11 & 1.33 & & & \\
\hline & 1.00 & 2.13 & 1.78 & 2.50 & 1.44 & 1.40 & 1.85 & & & \\
\hline & 2.00 & 2.23 & 2.13 & 1.89 & 1.60 & 1.14 & 1.76 & & & \\
\hline & 3.00 & 1.93 & 1.22 & 1.73 & 1.34 & 1.24 & 1.44 & & & \\
\hline Mean (NAA) & & 1.78 & 1.69 & 1.86 & 1.42 & 1.28 & & & & \\
\hline L.S.D.(0.05) & & & & & & & & 0.23 & 0.23 & 0.51 \\
\hline \multicolumn{11}{|c|}{ ( c ) Mean number of leaflets formed /prpbagule: } \\
\hline & 0.00 & 4.24 & 6.51 & 6.50 & 6.48 & 4.67 & 5.68 & $* *$ & $* *$ & $* *$ \\
\hline & 0.50 & 4.67 & 8.22 & 8.73 & 7.66 & 6.98 & 7.81 & & & \\
\hline & 1.00 & 9.31 & 10.77 & 10.80 & 8.30 & 7.02 & 9.23 & & & \\
\hline & 2.00 & 7.44 & 10.57 & 10.50 & 8.67 & 7.76 & 9.71 & & & \\
\hline & 3.00 & 9.13 & 6.83 & 6.20 & 5.53 & 5.43 & 6.65 & & & \\
\hline Mean (NAA) & & 8.39 & 8.46 & 8.54 & 7.32 & 6.37 & & & & \\
\hline L.S.D. $(0.05)$ & & & & & & & & 0.58 & 0.58 & 1.30 \\
\hline \multicolumn{11}{|c|}{ (d) mean number of roots formed /propagule: } \\
\hline & 0.00 & 0.34 & 1.70 & 1.84 & 2.99 & 3.37 & 2.07 & $* *$ & $* *$ & $* *$ \\
\hline & 0.50 & 2.88 & 5.30 & 6.57 & 6.00 & 4.60 & 5.07 & & & \\
\hline & 1.00 & 3.52 & 5.64 & 7.42 & 7.02 & 6.10 & 5.93 & & & \\
\hline & 2.00 & 3.10 & 6.95 & 7.42 & 6.00 & 5.93 & 5.88 & & & \\
\hline & 3.00 & 2.97 & 6.43 & 6.81 & 6.54 & 5.15 & 5.36 & & & \\
\hline Mean (NAA) & & 2.58 & 5.21 & 5.95 & 5.53 & 5.03 & & & & \\
\hline L.S.D.(0.05) & & & & & & & & 0.46 & 0.46 & 1.03 \\
\hline
\end{tabular}

L.S.D. $(0.05)=$ Least significant difference test at 0.05 level of probability*, **: Significant or highly significant.

For shoot length and roots formation, data presented in Table (3) and photo (3) shows that combination of IBA and NAA concentrations induced the increase in elongation of shoot length. Here, it was found that the shoots were tallest $(6.86 \mathrm{~cm})$ at $1.00 \mathrm{mg} / 1$ of IBA. Also, there were significant differences in shoot length between the different concentrations of IBA.

For the interaction between NAA and IBA, results showed that the tallest shoots were achieved when IBAwas at $1.00 \mathrm{mg} / 1$ and NAA at $0.50 \mathrm{mg} / 1(8.22 \mathrm{~cm})$. There was a steady increase in number of roots in the rooting stage, the greatest number of roots (7.42) at 1.00 or $2.00 \mathrm{mg} / \mathrm{l} \mathrm{IBA}+0.50 \mathrm{mg} / \mathrm{l} \mathrm{NAA}$ were obtained when compared with other treatments. This result could be explained by the fact that auxin induced a number of responses which involved cell division, cell enlargement, protein and nucleic acids synthesis which are concomitants of auxin-induced growth and changes in wall plasticity of plant cell and increased apical dominance as there are essential and rapid processes involved in growth and elongation (Wilkins,1989). Our results were further confirmed by the previous findings of Komalacalli and Rao (2000); Awal et al. (2005); and Waseem et al. (2011) who suggested auxin for root induction and development. 
The in vitro roots were successfully induced by using $5.0 \mathrm{mg} / \mathrm{l}$ of 2,4-D, (Sana et al. 2012). Taha et al. (2011) reprted that the best result of in vitro rootlets/shoot formation of Thevetia species were recorded with MS+ $1 \mathrm{mg} / \mathrm{l}$ NAA. In vitro elongated shoots rooted on MS medium supplemented with IBA $(0.5 \mathrm{mg} / \mathrm{l})(\mathrm{Zibbu}$ and Batra , 2010.).

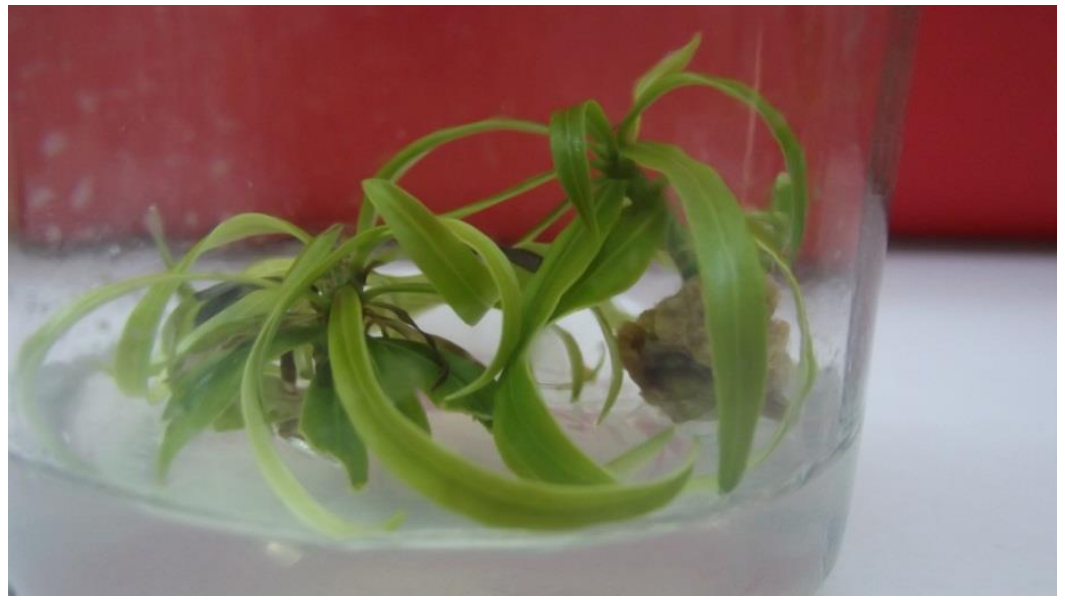

Photo 2. Multiplication stage of newlyformed Thevetia shoots of initiation stage cultured on WPM $+3.0 \& 4.0$ $\mathrm{mg} / \mathrm{l} \mathrm{KIN}+0.50 \mathrm{mg} / \mathrm{l} \mathrm{NAA}$
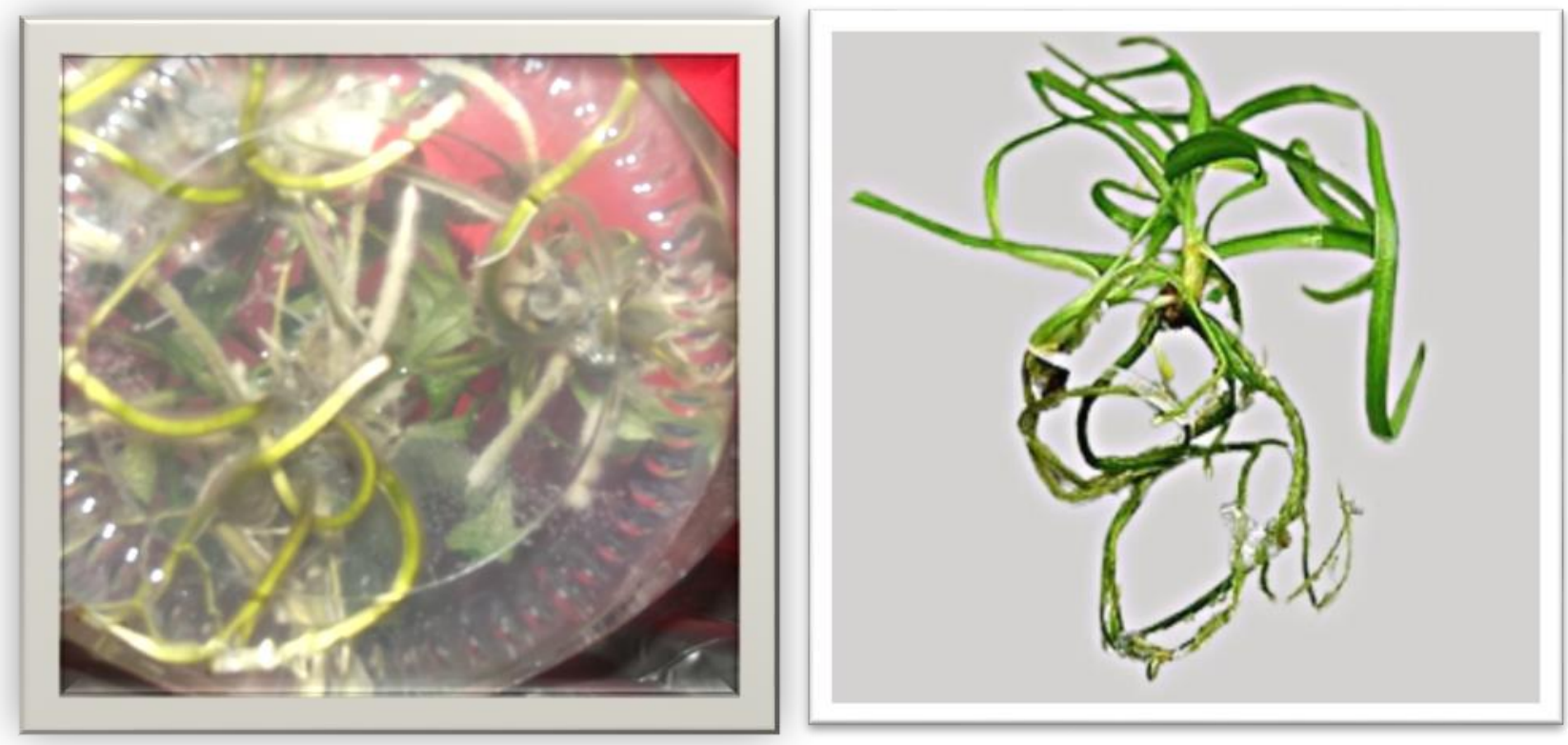

Photo 3. Rhizogenesis of Thevetia microshoots in the multiplication stage, upon culture and after for 35 days on WP medium fortifited with $2.00 \mathrm{mg} / \mathrm{IBA}$ and $0.50 \mathrm{mg} / \mathrm{l}$ NAA 
The Data in Table (4) and foto(4) clearly show that different WPM salt concentrations $(0.00,2.00,4$.00and $\left.6 \mathrm{~g} / \mathrm{L}^{-1}\right)$ had highly significant effects on growth and development of Thevetia peruviana culture in vitro. It is quite clear that the shoot length, number of shootlets, number of leaves, number of roots, fresh and dry weights of shootlets produced per explant were the highest in the case of control and with $2.00 \mathrm{~g} / \mathrm{L}^{-1}$ salt $(\mathrm{NaCl})$ as compared to 4.00 and $6.00 \mathrm{~g} / \mathrm{L}^{-1}$ where the best results were $(6.10 \mathrm{~cm}, 13.39,18.25$ and4.20), respectively.

The various treatments of the salt caused a significant effect on endogenous pigments such as chorophyll $\mathrm{a}$ and $\mathrm{b}$ in the shootlets tissues after 45 days at the end of the experiment (photo 4) .

Using WPM medium amended with $\mathrm{KIN} 3 \mathrm{mg} / \mathrm{l}$ $+\mathrm{NAA}$ at $0.50 \mathrm{mg} / 1$ with $0.00 \& 2 \mathrm{~g} / \mathrm{L}^{-1} \mathrm{Na}^{+} \mathrm{Cl}^{-}$produced shootlets tissues having the highest amounts of chlorophyll -a and $-\mathrm{b}$, while the lowest determined in shootlets tissues growing on WPM medium of $6.00 \mathrm{~g} / \mathrm{L}^{-1}$ $\mathrm{Na} \mathrm{Cl}$. Concerning the carotenoids in the shootlets tissues at the four concentrations of salt, the result was not significant of all treatments in formed plants (Table 4) and the explants showed good tolerance to salt in vitro, and all the explants formed shootlets (photo4). However, the negative consequences some explants died that death was least salt -tolerant with the additions of $6 \mathrm{gL}$ of $\mathrm{NaCl}$. Similar results indicated for explants of grapevine rootstocks (Tronocoso et al. 1999a) or olive (Tronocoso et al. 1999b). Also, Sawsan et al. (2005) reported that the highest amounts of chlorophyll $-\mathrm{a}$ and $-\mathrm{b}$ and caroteniodes were dectected in shootlet tissues grown on MS-medium provide with ether NAA at $0.1 \mathrm{mg} / 1$ plus at 3,4 or $5 \mathrm{mg} / 1$ or NAA at $0.2 \mathrm{mg} / 1$ plus $\mathrm{BAP}$ at $3 \mathrm{mg} / \mathrm{l}$ concentration.

Salinity also affected the development of the in vitro plant organs. While low concentrations of $\mathrm{NaCl}$ had no negative affect on the in vitro production of all plant organs, at high concentrations of $\mathrm{NaCl}$ the production decreased, especially at the $6 \mathrm{gL}^{-1} \mathrm{NaCl}$ mainly in the number of leaflets and number of shoots. This result had been supported by Greenway and Munns,(1980); Ashraf et al.(1986); Pasternak, (1987); Grattan and Grieve (1992.) and Carretero et al.(2007) reported that salinilty negatively affected on the survival rate, development, leaf water content, and mineral composition (mainly by accumulation of $\mathrm{Cl}^{-}$and $\mathrm{Na}^{+}$) of both in vitro and ex vitro Manihot plants, also, Joao et al.(2015)said that the in vitro multiplication of B. Zebrina shoots was enhanced by using $200 \%$ of MSsalts concentration and liquid medium.

At $4 \mathrm{gL}^{-1}$ the fresh and dry weights were significantly higher in explants, which was the high survival. The salt treatments affected the freash weight that decreased with application of $6 \mathrm{gL}^{-1}$ of $\mathrm{NaCL}$ in explants The salt treatments provoked accumulation of $\mathrm{Na}^{+}$and $\mathrm{CL}^{-}$in the explants (Table4). These accumulations were proportional to added $\mathrm{NaCL}$ concentrations in the medium, similar $\mathrm{Na}^{+}$and $\mathrm{CL}^{-}$ accumulations were indicated by Troncoso et al.(1999a) for grapevine rootstocks grown in vitro and by Troncos et al.(1999b) for olive plants grown in vitro. Thus, salt treatments affected survival and growth of Thevetia plants in vitro. However, $\mathrm{NaCL}$ applications up to $2 \mathrm{gL}^{-1}$ or $4 \mathrm{gL}-1$ increased production of plant in the indicating that thevetia showed relatively high salt torlerance in vitro. Dry weight was also affected by salinity, In table (4) are showed variations effects dry weight caused by the salt treatments expressed as compered of the control. In general, $6 \mathrm{gL}^{-1} \mathrm{NaCL}$ presented significant lowest dry weight. Also, salt addition clearly decreased fresh weight in high levels. As in the in vitro test, NaCL additions caused $\mathrm{Na}^{+}$accumulations, but without significant in carotenoids.

Thus, as indicated for the in vitro experiment, the greater salt torlerance of explants was not related to a lower uptake and accumulation of toxic saline ions, but probably a greater capacity to resist the stress situation of other nutrients were not apparently affected by salt (Teser and Devenport2003; Karimia et al.,2009). Khorami et al. (2011) noted that increasing accumulation of proline with enhancement $\mathrm{NaCl}$, the strategies plants adapted to cope up with stress conditions. Effect of salinity stress on proline accumnlation plant tissues, coud be expland by the fact that salt stress sometimes has variations in the arrangement of $\mathrm{N}$ containing mixtures, particulary of proteines and free amino acids. Most recognized is the accretion of praline, that is usually functionse as a pointer of salt stress (Ashraf and Foolad, 2007). By enhancing the free amino acids this may has an indicator of tolerance to salinity. Proline helps stabilizing sub-cellualr structures (e. g. proteins and membranes), scavenging free radicals (Apel and Hirt, 2004), and defending cellular redox potential below stress conditions (Ashraf and Foolad, 2007). 
Table 4. Effect of salt $(\mathrm{NaCl})$ concentrations in the medium of in vitro shoot culture of Thevetia peruviana plants after 45 days

\begin{tabular}{|c|c|c|c|c|c|c|}
\hline \multirow{2}{*}{ characters } & \multicolumn{4}{|c|}{ Treatments $\quad\left(\mathrm{gL}^{-1} \mathrm{NaCL}\right)$} & \multirow{2}{*}{ sign } & \multirow{2}{*}{ LSD } \\
\hline & $\mathbf{0}$ & 2 & 4 & 6 & & \\
\hline $\begin{array}{l}\text { Mean shoot length } \\
\text { (cm)/propagule }\end{array}$ & 3.32 & 2.84 & 3.10 & 2.07 & $* *$ & 0.42 \\
\hline $\begin{array}{l}\text { Mean number of } \\
\text { shoots } \\
\text { formed/propagule }\end{array}$ & 3.82 & 4.20 & 3.15 & 2.65 & $* *$ & 0.48 \\
\hline $\begin{array}{l}\text { Mean number of } \\
\text { leaflets } \\
\text { formed/propagule }\end{array}$ & 17.86 & 18.25 & 16.13 & 12.53 & $* *$ & 1.61 \\
\hline $\begin{array}{l}\text { Number of roots } \\
\text { formed/propagule }\end{array}$ & 6.10 & 5.32 & 4.22 & 3.28 & $* *$ & 0.19 \\
\hline $\begin{array}{l}\text { survival rate } \\
\text { ofshootlets } \%\end{array}$ & 80.00 & 66.67 & 53.33 & 40.00 & $* *$ & 1.38 \\
\hline Fresh weight(mg) & 6.27 & 5.57 & 2.07 & 2.52 & $* *$ & 0.60 \\
\hline Dry weight(mg) & 2.16 & 2.70 & 0.87 & 0.90 & $* *$ & 0.25 \\
\hline $\begin{array}{l}\text { Chlorophyll(A) } \\
(\mathrm{mg} / 100 \mathrm{~g})\end{array}$ & 28.27 & 25.56 & 19.16 & 16.13 & $* *$ & 4.36 \\
\hline $\begin{array}{l}\text { Chlorophyll(B) } \\
(\mathrm{mg} / 100 \mathrm{~g})\end{array}$ & 25.50 & 21.38 & 19.45 & 14.86 & $* *$ & 2.20 \\
\hline $\begin{array}{l}\text { Carotenoids } \\
\text { conc. }(\mathrm{mg} / 100 \mathrm{~g})\end{array}$ & 21.57 & 20.86 & 19.79 & 20.08 & ------------ & ns \\
\hline Proline conc. $(\mu \mathrm{g} / \mathrm{g})$ & 2.58 & 4.54 & 10.21 & 13.39 & $* *$ & 1.37 \\
\hline $\begin{array}{l}\text { Carbohydrate } \\
\text { content } \%\end{array}$ & 4.91 & 4.58 & 4.85 & 6.58 & $* *$ & 0.82 \\
\hline Acclimatization $\%$ & 73.00 & 70.00 & 60.00 & 40.00 & $* *$ & 2.39 \\
\hline
\end{tabular}
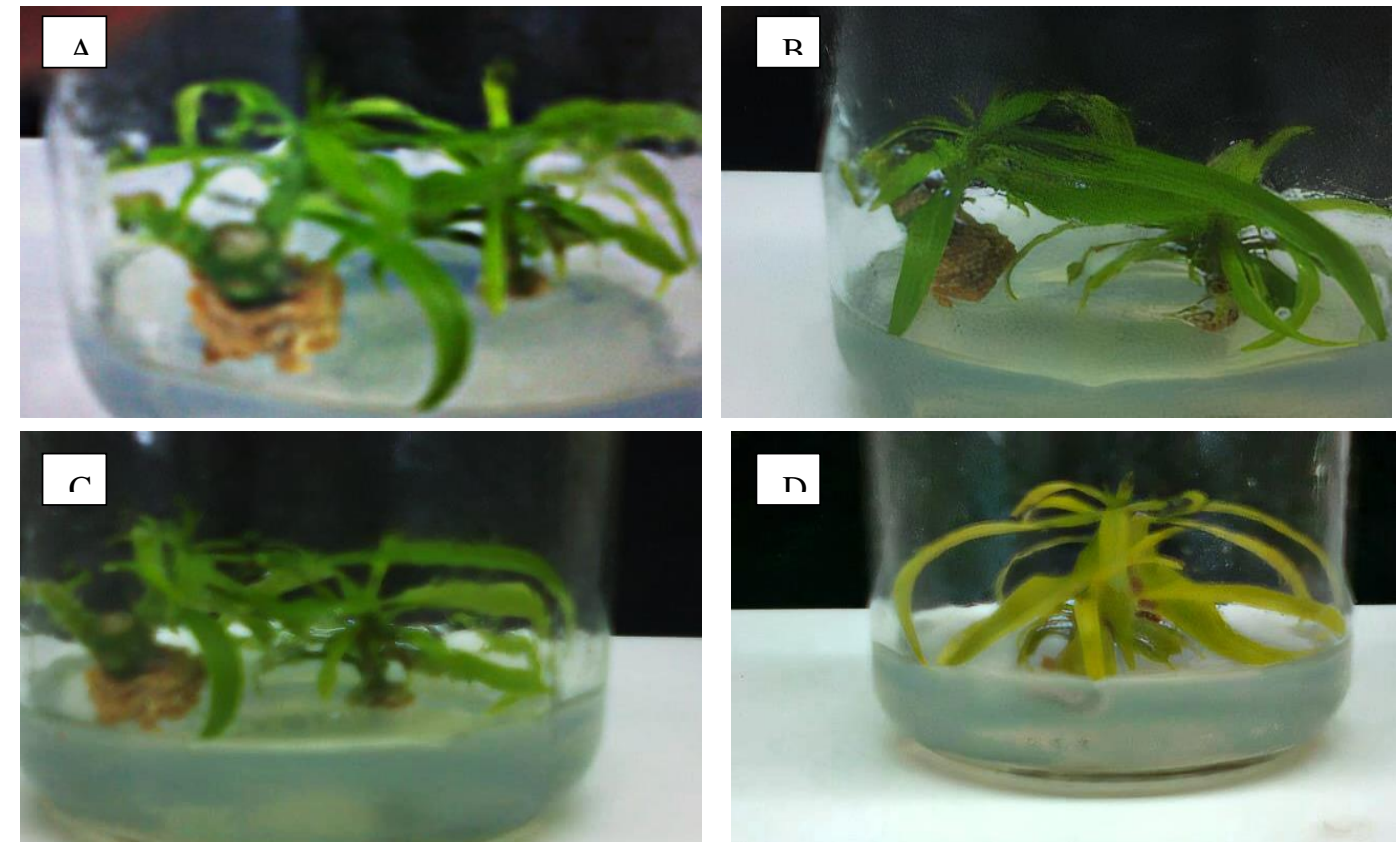

Photo 4. Direct in vitro organogenesis in the Thevetia explants A, B, C and D in WPmedium with NaCl concentrations at $0.00,2.00,4.00$ and6.00gL $\mathrm{L}^{-1}$ from left to right 

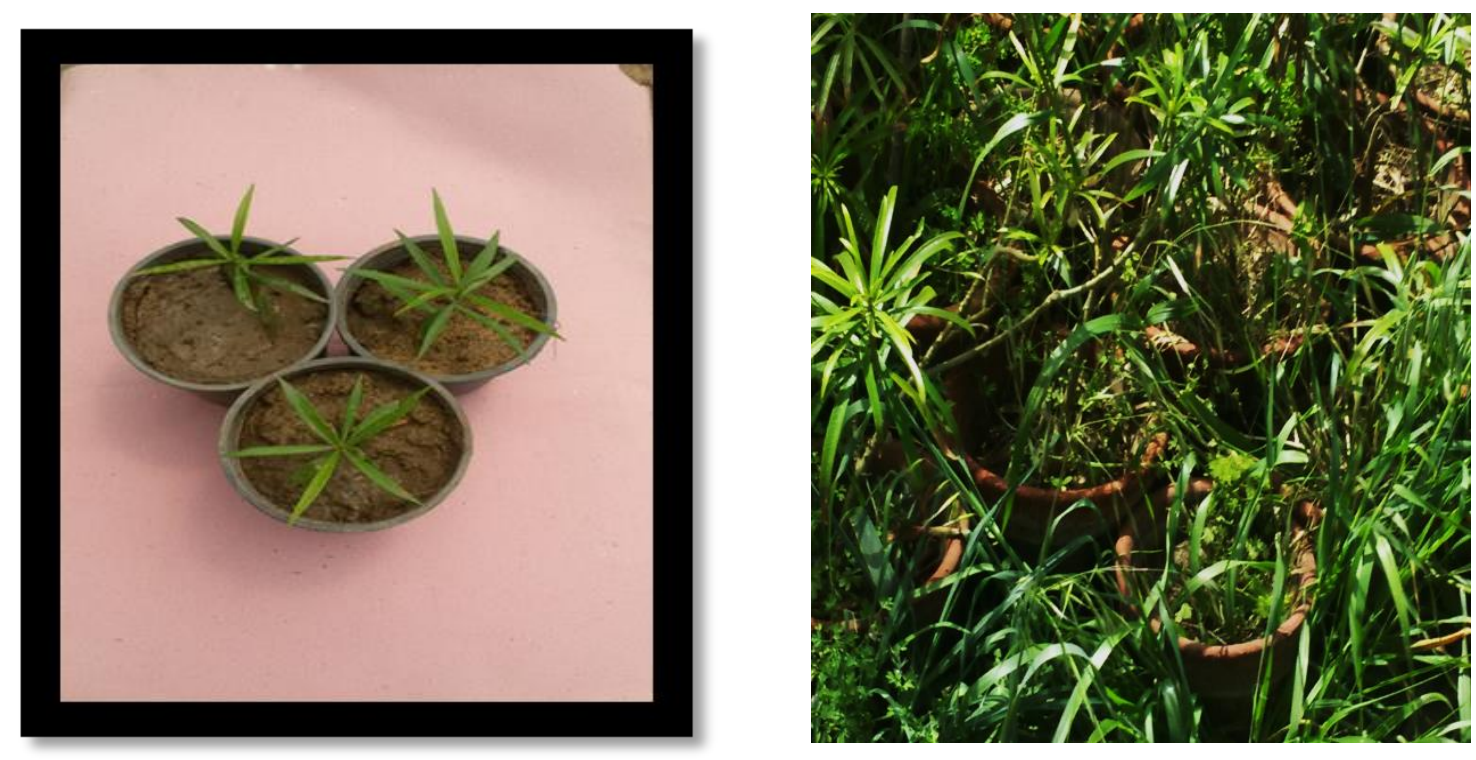

Photo5. Acclimatized Thevetia tissue culture plants derived from plants ex vitro

\section{Acclimatization stage}

According to the results, there was a correlation between the in vitro and ex vitro responses of the explants to salt treatments.

Acclimatization of in vitro grown plants is an important step in micropropagation (Smart, 2008; Rout et al.,2006). The in vitro grown plantlets were transferred to the green house for the acclimatization $e x$ vitro. The potting mix (sand and soil) (1:3), routinely used in the nurseries of our institute, was found suitable for the hardening of the plants The survival rate of the ex vitro grown plants was $73 \%, 70 \%, 60 \%$ and $40 \%$ with using $0.00,2.00,4.00$ and $6.00 \mathrm{gNaCL}$, respectively.

\section{CONCLUSIONS}

It could be concluded that there is a possibility to propagate Thevetia peruviana by micropropagation. The study showed the efficiently of the in vitro initiation, multiplaction, shoot proliferation and rooting of nodal segements of thevetia plants. Notably, the present experiments demonstrated that an in vitro technique in the multiplication stage can be efficiently used for studies of the reaction of thevetia plants to sodium salt, it showed good tolerance to salinity at low concentrations $(2 \& 4 \mathrm{~g} / \mathrm{L})$, but with increasing concentrations of sodium chloried $\left(0-6 \mathrm{~g} / \mathrm{L}^{-1}\right)$ in WPmedium inhibited multiplication of thevetia and shoots, reduced the mean length of newly developed shoots. Generally, the growth was enhanced with increasing salt concentrations in the medium.

\section{REFERENCES}

Abdul-Qader, N.E. 1999. Propagation of some difficult-to-root ornamental plants by tissue culture. M.S. Thesise, Fac. Agric. Sci., Ain Shams, Univ.

Abou Dahab, A.M., A. M. A. Habib, Y. A. Hosni and A. M. M. Gaber. 2005. Effect of MS- salt strength,sucrose and IBA concentration and acclimatization media on Ruscus hypoglossum L. micropropagation. Arab J. Biotech., Vol.8, No. (1) Jan. 141-154.

Apel, K. and H. Hirt .2004. Reactive oxygen species: metabolism, oxidative stress and signal transduction. Annual Review of Plant Biology. 55: 1331-1341.

Ashraf, M., T. McNeily and A. D. Bradshaw. 1986. The response of selected salt-tolerant and normal lines of four grass species to $\mathrm{NaCl}$ in sand culture. New Phytol. 104:453-461.

Ashraf, M. and M. R. Foolad. 2007. Roles of glycine betaine and proline in improving plant abiotic stress resistance. Experimental Environmental Botany. (59): 206-216.

Ashish, S. and R. A. Sharma. 2011. Micropropagation of Croton Bonplandium Ball. Inter. Res.J. Pharm (IRJP). 2(10):82-86.

Awal, S. M. A., M. R. A. Alam and M. N. U. Hassan. 2005. In vitro propagation of pointed gound (Trichosanthes dioica Roxb.) from shoot tips Biotech. 4(3):221-224.

Bates, L., R. Waldern and I. Teare. 1973. Rapid determination of free proline for water stress studies. Plant and Soil.39:205-207.

Bhattacharya, P., S. Dev and B.S. Bhattacharya.1990. Rapid mass propagation of Chysanthemum morifolium by callus derived from stem and leaf explants PL. Cell RFep.9:439442 . 
Carretero, C.L., M.Cantos, J.L.Garcia and A. Troncoso. 2007.In vitro-exvitro salt(NaCL) tolerance of cassava (Manihot esculenta Crantz) plants. In vitro Cell. Dev. Biol. 43:364-369.

Chitra P. and V. Madhusoodanan . 2005. Influence of auxins in direct in vitro morphogenesis of Euphorbia nivulia, a lectinaceous medicinal plant. In Vitro Cell. Develop. Biol-Pl. 41:314-319.

Davies,P.J.n.1995. Plant Hormones: Physiology, Biochemistry and Molecular Biology. Dordrecht: Kluwer.833p.

EL-Shamy, M. A., S. S. Ahmed and A. Ibrahim. 2010.Effect of media on propagation of Magnolia grandiflora with tissue culture technique. J. Biol.Chem.Environ.Sci.5(4):277-291.George, E.F., M.A. Hall and G.J.D. Klerk. 2008. Plant propagation by tissue culture $3^{\text {rd }}$ Edition. Springer.

George, E.F. and P.D. Sherrington. 1984. Plant Propagation by tissue Culture. Exegeetic Ltd., Basingtoke, U.K.709P.

Gomez, K. and A. A.Gomez. 1984. Statistical procedues for Agricultural Research ( $2^{\text {nd }}$ ed.). An International Rice Researcher Institute Bok. A Wiley Interscience Puplisher, New York.

Http://www.esf.edu/efb/course/EFB530/EFB530Syllabus.htm.

In:Jain,S.M. and S.J.Ochatt (eds.,)Protocols for In Vitro Propagation of Ornamental Plants, Methods in Molec. Biol. 589:187-195.

Grattan, S. R. and C. M. Grieve. 1992.Mineral element acquisition and growth response of plants grown in saline environments. Agric. Ecosyst. Environ. 38:275-300.

Greenway, H. and R. Munns. 1980 Mechanisms of salt tolerance in non-halophytes. Annu. Rev. Plant Physiol. 31:149-190.

Hedge, J.E. and B. T. Hofreiter.1962. In: Carbohydrate Chemistry, 17(Eds. Whistler R. L. and Be Miller,J.N.), Academic Press, New York.00.

Karimia, E., A. Abdolzadeha and H. R. Sadeghipour. 2009. Increasing salt tolerance in Olive, Olea europaea L. plants by supplemental potassium nutrition involves changes in ion accumulation and anatomical attributes. International Journal of Plant Production. 3 (4): 49-60.

Khorami, R., A. Safarnejad and M. Shourvarzi. 2011. Effect of salt stress on ion distribution and proline accumulation in Foeniculum vulgare using in vitro technique. I.J.S.N. 2(2): 168-175. 48.

Klimaszewska, K. 1981.Plant regeneration from petiole segment of some species in tissue culture. Actabotan. 34(1):5-28.

Komalacalli, N. and M.V.Roa. 2000. In vitro micropropagation of Gymnemam Slyvestre. Amultipurpose medicinal plant.Pl.Cell,Tiss,Org.Cul. 61:97-105.

Kucukahmetler,O. 2002. The effects of salinity on yield and quality of ornamental plants and cut flowers. Acta Hortic.573:407-414.

Kumar, A. 1992. Somatic embryogenesis and high frequency plantlet regeneration in callus culture of Thevetia peruviana L. Plant cell Tissue and Organ Cult. 31(1):4750.
Lemos, E.P. and J. Black .1996. Micropropagation of juvenile and mature Annona muricata, L. J. Horti .Sci. Biotech. 71:395-405

Lloyd, G. and B. McCown. 1980. Commercially feasible micro-propagation of mountain laurel, Kalmia latifolia by use of shoot tip culture. Proc. Intl. Pl. Prop. Soc. 30:421427.

Martins, J. P. R., P. M. Pasqual, A.D. Martins and S. Francisca. 2015. Effects of salts and sucrose concentrations on invitropropagation of Billbergia zebrine(Herbert)Lindley (Bromeliaceae)AJCS 9(1):85-91.

Moran, R. 1982. Formula determination of chlorophyll pigment extracted with $\mathrm{N}, \mathrm{N}$ diethyl formamide. Plant physiol. 69:1376-1381.

Nasib, A., K. Ali and S.Khan. 2008. In vitro propagation of croton (Codiaeum variegatum). Pak.J.Bot. 40(1):99-104.

Nesy, E. A., J. Padikkala and L. Matheew. 2015. In vitro plant regeneration of Theveta neriifolia, Juss from internode explants Via indirect organogenesis.Int J.Pharm Pharm Sci. 7(1):169-172.

Omino E. A. and J.O. Kokwaro. 1993.Ethanobotoanty of Apocynaceae species in Kenya. Journ.of Ethanopharm. 40:167-180

Pasternak, D. 1987. Salt tolerance and crop production-a comprehensive approach. Annu. Rev. Phytopathol. 25:271-291.

Pawlowska, B. and A. Bach.2010. Effect of salt stress on Rose 'New Dawn' in in vitro culture. Ecol. Chem. And Eng. 16-9.

Priyanaka, S., G.Krian and A.R.Gill. 2011. The influence of plant growth regulators, explants nature and sucrose concentration on in vitro callus growth of Thevetia peruviana Schum. A. J.Bio. 3 (3):280-292.

Raven,P.H., R.F.Evert and S.E.Eichhorn. 1992. Biology of plants. New York: Worth. 545-572.

Rout, G.R., A. Mohapatra and S. Mohan Jain. 2006. Tissu culture of ornamental pot plant: A critical review on present scenario and future prospects. Biotech. Adv. 24:531-560.

Sana, S., S. Mathew and R.S. Krishnapriya. 2012. Organogenesis and somatic Embryogenesis in various Cultivars of Codiaeum variegtum (L.) Global Advanced Res. J. Biotec. 1(3):040-047.

Salisbury, F.B. and C.W. Ross. 1992. Plant Physiology. Belmont, A: Wadsworth. 357-407.

Sawsan, S. S., T.A. Aahab and E. M. A. Youssef. 2005. In vitro propagation of cactus (Cereus peruvianus L.). Arab J. Biotech. 8 (1) : 169-176.

Smart, S. 2008. EFB530 Plant Physiology, Cytokinins and Cell division, EFB530 plant Physiology-Syllabus with lecture notes-spring.

Steel, R.G.D., J.H. Torrie and D.A. Dickie. 1997. Principles and procedures of statistics-a biometric approach. Thired edition. McGraw-Hill Publishing Company. Toronto. 
Taha, H. S., S.H. Farag, K.A.Shams, N.S.Abdel-Azim and M.M.Seif El-Nasr. 2011. In vivo and in vitro studies on Thevetia species Growing in Egypt II.Establishment of in vitro tissue culture system and production of cardiac glycosides. J. of Amer. Sci. 7(3).

Tester, M. and R. Devenport. $2003 \mathrm{Na}+$ tolerance $\mathrm{Na}+$ transport in higher plants. Annal Bot. 91: 503527

Troncoso, A., C. Matte, M. Cantos and S. Lavee 1999a. Evaluation of salt tolerance in vitro-grown grapevine rootstock varieties. Vitis. 38:55-60.

Troncoso, A., J. Liñán, J.Troncoso, H. Rapoport and M. Cantos. 1999b. In vitro obtaining of salt tolerant olive plants. International Meeting on Scientific Innovations and Their Applications to Oliviculture. Florence (Italy): International Olive Council (COI) and Accademia dei Georgofili.
Waseem,K., M.S.Jelani, M.S,Khan, M.Kiran and G.Khan. 2011. Efficient in vitro argeneration of chrysanthemum (Chrysanthemum morifolium L.) plantlets from nodal segments. Afri.J.Biotechn. 10(8):1477-1484.

Wellburn, A. R. 1994. The spectral determination of chlorophylls a and $\mathrm{b}$, as well as total carotenoids, using various solvents with spectrophotometers of different resolution. J. Plant Physiol. 144(3):307-313.

Wilkins, M.B. 1989. Advanced plant physiology. The Bath Press, Avon. 13-15.

Zibbu, G. and A. Batra. 2010. Effect of adenine sulphate on organogenesis via leaf culture in an ornamental plant: Thevetia peruviana (pers.) schum. Inter. J. of Pharm. \& Bio-Sci. 1(2): 1-9.

\section{الملخص العربي \\ انتاج نباتات تيفتيا متحمله للملوحه بطريقه زراعه الانسجه \\ هدى اسماعيل محمد الجداوى}

بتركيز • .ـمليجرام / لتر • بالاضافه الى 0.50 مليجرام /لتر

من الاوكسين NAAوكانت افضل بيئه للاستطاله فى بيئه

التضاعف هى البيئه المزوده بالاوكسين NAA عند .0. .

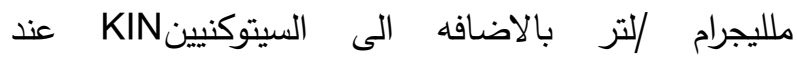

تركيز . .. (مليجرام/لتر .وكذلك اظهرت مجاميع جذرية قويه

وسليمه عند تزويد البيئه الاوكسينNAA بتركيز .0. .

ملليجرام /لتر أضافه الى الاوكسين BA ابتركيز . .. امليجرام

/لتر .وقد أظهرت الدراسه تحمل نباتات التافيتيا لدرجه

الملوحه فى بيئات النمو حيث اظهرت جوده عاليه فى

النمووعدد الفروع والنمو الخضرى عامه وكذلك الجذور

خصوصا مع التركيزات المنخفضه من الاملاح ب\&ء جم/لتر

وكلها معنويه واعطت نتائج جيده نسبيا مع التركيزات المرتفعه من الاملاح حيث انخفض عدد الفروع واستطالتها وكذلك عدد الجذور والاوراق بالمقارنه مع الكنترول والتركيزات المنخفضه من الملوحه ،وقد تم أقلمه جميع النباتات الناتجه معمليا بنجاح حيث تم استخدام خلطه من

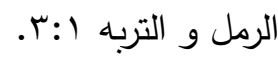

إجريت هذه الدراسه فى معمل زراعه الأنسجه - قسم

الانتاج النباتى -كليه الزراعه سابا باشا- جامعة الأسكندريه

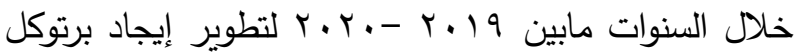

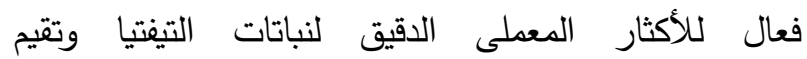
تأثيرمنظمات النمو والاملاح (كلوريد الصوديوم) ومدى تحمل النبات معمليا لارجه الملوحه فى بيئات النمو معمليا ومدى تاثير ذلك على النمو ومرحله الاقلمه. ولقد تم أستخدام عقل معل ملته ساقيه من نباتات التيفتيا الناميه بحدائق قسم بحوث الزينه بأنطونيادس خلال دراسة معمليه لأستحثاث اكثار تضاعف لإن المجاميع الخضريه ـ تمت زراعه المجاميع الخضريه المتكونه خلال مرحلة البدء او التشين على بيئات مختلفه للتضاعف او الاكثار للحصول على اعداد كبيره متضاعفه من تلك مركئ المجاميع الخضريه وكذلك لتقيم ومقارنه تاثير منظمات النمو والاملاح على نمو هذه النباتات معمليا، هذا بالاضافه الى اقلمه تلك النباتات خارج المعمل، بنجاح. وكانت بيئات النمو هى البيئات المضاف لها السيتوكنيينKIN بالاضافه الى تركيزات مختلفه من الاوكسين NAA، وكانت افضل بيئه لتكوين المجاميع الخضريه تحت الظروف المعمليه هى بيئه أكثار النباتات الخشبيه (WPM) المزوده بالسيتوكنيين 